\title{
EFEKTIVITAS AWIG-AWIG DALAM PENGATURAN KEHIDUPAN MASYARAKAT NELAYAN DI PANTAI KEDONGANAN BALI
}

\author{
The Effectiveness of Awig-awig in Livelihood Arrangements of Fishing Community in \\ Kedonganan Beach
}

\author{
Tyas Widyastini*) dan Arya Hadi Dharmawan
}

Departemen Sains Komunikasi dan Pengembangan Masyarakat, Fakultas Ekologi Manusia, IPB

*)Email : tyaswidyastini@gmail.com

\begin{abstract}
The purpose of this study is to analyze the effectiveness of Awig-awig in the livelihoodarrangements of fishing community. Awig-awig is one of customary law in Bali and an existing law and made by indigenous people as guide to behave in social interaction. Awig-awig contains a set of rules, written or unwritten which is based on Hindu Philosopy Tri Hita Karana. This study also propose to understand about the knowledge, understanding and implementation of fishers to Awig-awig which arrange the livelihood of fishing community. The respondents of this research were indigenous and migrant fishers who are usually undertake fishing activities in Kedonganan Beach. There are difference in the knowledge, understanding and implementation to each rule in Awig-awig, either for indigenous fishers or migrant fishers. The effectiveness of Awig-awig can be known from the number of rule violations, strict sanction, intensive socialization, officers who did control and awareness of fishers.
\end{abstract}

Keywords: awig-awig, effectiveness, livelihood Arragements

\begin{abstract}
ABSTRAK
Tujuan dari penelitian ini yakni untuk menganalisis efektivitas Awig-awig pengaturan kehidupan masyarakat nelayan. Awig-awig merupakan pranata sosial di Bali dan suatu peraturan yang dijalankan, awig-awig dibentuk oleh penduduk lokal sebagai pedoman untuk berperilaku dalam interaksi sosial. Awig-awig terdiri dari sekumpulan aturan, tertulis atau tidak tertulis berlandaskan filosofi hindu Tri Hita Karana. Penelitian ini juga bertujuan untuk mengetahui tentang pengetahuan, pemahaman dan implementasi nelayan terhadap awig-awig yang mengatur kehidupan masyarakat nelayan. Responden penelitian ini adalah nelayan lokal dan pendatang. Efektivitas awig-awig dapat diketahui dari jumlah pelanggaran aturan, saksi yang tegas, sosialisasi yang intensif, petugas yang melakukan kontrol, dan penghargaan terhadap nelayan.
\end{abstract}

Kata Kunci : awig-awig, efektivitas, peraturan kehidupan

\section{PENDAHULUAN}

\section{Latar Belakang}

Indonesia merupakan negara maritim terbesar di dunia dengan dua pertiga wilayahnya terdiri dari wilayah perairan. Indonesia sebagai negara kepulauan memiliki 18306 pulau yang dipersatukan oleh laut dengan panjang garis pantai $81000 \mathrm{KM}$. Laut di Indonesia mempunyai potensi yang sangat besar. Potensi sumberdaya tersebut ada yang dapat diperbaharui (renewable resource) seperti sumberdaya perikanan dan energi yang tidak dapat diperbaharui (nonrenewable resources) seperti sumberdaya minyak dan gas bumi serta mineral. Selain itu juga terdapat potensi lain yaitu jasa lingkungan kelautan yang dapat dikembangkan untuk pembangunan ekonomi nasional seperti pariwisata bahari, industri maritim dan jasa angkutan .

Wilayah pesisir atau pantai di Indonesia juga terkenal dengan sumberdaya alamnya yang indah dan melimpah. Kekayaan alam pesisir yang melimpah dan indah tersebut perlu dijaga kelestariannya. Menurut Bengen (2001), pantai atau wilayah muka pesisir adalah bagian dari kawasan pesisir yang paling produktif. Pantai merupakan suatu kawasan pesisir beserta perairannya dimana daerah tersebut masih terpengaruh baik oleh aktivitas darat maupun laut. Garis pantai merupakan suatu garis batas pertemuan antara daratan dengan air laut.Posisinya bersifat tidak tetap, dan dapat berpindah sesuai dengan pasang surut air laut dan erosi pantai yang terjadi.Pantai terletak antara garis surut terendah dan air pasang tertinggi. Sumberdaya pesisir adalah sumber daya binaan/buatan dan jasa-jasa lingkungan yang terdapat di dalam wilayah pesisir. Pengelolaan sumberdaya pesisir pada hakekatnya adalah suatu proses pengontrolan tindakan manusia atau masyarakat di sekitar kawasan pesisir agar pemanfaatan sumberdaya alam dapat dilakukan secara bijaksana dengan mengindahkan kaidah kelestarian lingkungan (Supriharyono 2000 dalam Stanis 2005). 
Menurut Dahuri (2004) wilayah pesisir memiliki tiga ciri karakteristik unik dari ekosistem pesisir yang membuat pengelolaannya lebih menantang (challenging) dibandingkan dengan pengelolaan pada ekosistem di darat maupun dilaut lepas (high seas). Ketiga ciri tersebut yaitu sistem lingkungan alam yang kompleks, pemanfaatan yang sangat beragam, dan kepemilikan.Wilayah pesisir yang rezim kepemilikannya akses terbuka cenderung rentan terjadi kerusakan terhadap sumberdaya alamnya. Hal ini karena hak dan kewajiban mengenai pengelolaan sumberdaya tersebut tidak ada yang mengatur sehingga setiap orang bebas mengakses dan memanfaatkannya. Hak dan kewajiban atas akses dan pengelolaan sumberdaya yang tidak diatur dapat menyebabkan tragedi kepemilikan bersama sumberdaya alam atau tragedy of commons. Tragedi kepemilikan bersama ini muncul ketika manusia mengambil sumberdaya yang menjadi milik bersama untuk kepentingan pribadi sehingga merugikan makhluk hidup lain.

Menurut Hutagalung (2010), terjadinya tragedi kepemilikan bersama disebabkan oleh pandangan yang menginginkan untuk meraih keuntungan yang banyak untuk kepentingan sendiri daripada membagi-bagikannya kepada manusia lain dan masing-masing mendapat jatah sedikit. Akses dan pengolahan yang dilakukan secara bebas tersebut pada awalnya akan terasa menguntungkan bagi pihak yang memakai banyak sumberdaya alam, namun pada akhirnya ketersediaan sumber daya alam akan habis dan justru memberikan dampak negatif bagi pihak yang memakai dan bagi manusia lain. Habisnya ketersediaan sumber daya alam akan memberikan dampak negatif terhadap kelestarian lingkungan pesisir. Rezim kepemilikan akses terbuka yang menyebabkan tragedi kepemilikan bersama tersebut harus segera ditangani agar tidak merusak kelestarian lingkungan pesisir secara terus menerus. Kelembagaan mempunyai peran dalam memberikan aturan-aturan bagi masyarakat dalam mengelola dan menjaga lingkungan pesisir agar tetap terjaga kelestariannya. Kelembagaan mencakup kelembagaan formal dan kelembagaan informal, dimana dalam kelembagaan informal terdapat kelembagaan lokal yang dibentuk yang dibentuk oleh masyarakat sendiri dan kelembagaan formal dibentuk oleh pemerintah.

Menurut Koentjaraningrat (1990), pranata sosial adalah sistem kelakuan dan hubungan yang berpusat kepada aktivitas-aktivitas untuk memenuhi kompleks-kompleks kebutuhan khusus dalam kehidupan masyarakat. Kelembagaan sosial sering diartikan dengan pranata sosial. Kelembagaan lokal adalah pranata sosial di tingkat lokal. Wilayah pesisir yang pengelolaannya diserahkan kepada masyarakat setempat terdapat kelembagaan lokal yang mengatur sistem tata-kelakuan dan hubungan dalam kehidupan masyarakat. Salah satu bentuk kelembagaan lokal yaitu Awig-awig yang terdapat di daerah Bali. Awigawig yang terdapat di daerah Bali, masih banyak yang ditaati dengan baik oleh masyarakat sekitar.Awig-awig sebagai salah satu bentuk dari hukum adat, merupakan hukum yang hidup yang dibuat oleh masyarakat adat sebagai pedoman bertingkah laku dalam pergaulan hidup bermasyarakat (Astiti et al, 2011).Awig-awig mempunyai landasan filosofis Tri Hita Karana yaitu ajaran pada agama hindu yang pada intinya mengajarkan tentang keseimbangan antara manusia dengan Tuhan, manusia dengan manusia dan manusia dengan lingkungannya. Awig-awig berisi sekumpulan aturan baik tertulis maupun tidak tertulis beserta sanksi dan aturan pelaksanaannya. Kelembagaan lokal yang terdapat dalam wilayah pesisir tersebut berguna agar tidak terjadi penyelewengan atau pelanggaran yang dapat merusak sumber daya alam. Aturan-aturan yang terdapat pada kelembagaan lokal merujuk pada kearifan lokal yang dimiliki masyarakat. Menurut Sartini (2004), kearifan lokal adalah kebenaran yang telah mentradisi dalam suatu daerah yang terbentuk sebagai keunggulan budaya setempat dan merupakan produk budaya masa lalu yang patut secara terus-menerus dijadikan pegangan hidup. Bentuk-bentuk kearifan lokal dapat berupa bentuk nilai, norma, etika, kepercayaan, adat-istiadat, hukum dan aturan-aturan khusus.

Pantai Kedonganan terdapat di sebelah utara Pulau Bali, terletak di Desa Kedonganan Kecamatan Kuta Kabupaten Badung. Pantai Kedonganan status pengelolaannnya oleh pemerintah daerah diserahkan kepada masyarakat adat setempat namun tetap dalam pengawasan pemerintah. Desa Kedonganan yang wilayahnya terletak di pinggir pantai, terkenal dengan sebutan desa nelayan karena mayoritas penduduknya bekerja sebagai nelayan. Meskipun jumlah masyarakat yang bekerja sebagai nelayan berkurang seiring berjalannya waktu, namun Desa Kedonganan masih terkenal sebagai desa nelayan. Pantai Kedonganan yang masih terdapat banyak nelayan tersebut menarik perhatian para wisatawan untuk berkunjung. Para wisatawan tertarik untuk melihat perahu-perahu tradisional nelayan atau biasa disebut jukung, melihat kegiatan nelayan dalam menangkap ikan dan tertarik untuk berkeliling pantai menggunakan perahu nelayan. Para nelayan pun biasanya menyewakan perahu mereka pada wisatawan untuk berkeliling pantai. Untuk menjaga kelestarian lingkungan Pantai Kedonganan serta untuk mengatur perilaku nelayan dalam kegiatan penangkapan ikan, maka diberlakukan Awig-awig yang mengatur kehidupan masyarakat nelayan. Awig-awig yang berlandaskan filosofi ajaran Agama Hindu dan lekat dengan budaya Bali tersebut tidak hanya berlaku bagi nelayan pribumi tetapi juga berlaku bagi nelayan pendatang. Tulisan ini mengkaji tentang efektivitas Awig-awig yang merupakan pranata sosial dalam kehidupan masyarakat nelayan di Pantai Kedonganan.

\section{Masalah Penelitian}

1. Bagaimana bentuk Awig-awig yang mengatur kehidupan masyarakat nelayan di Pantai Kedonganan?

2. Bagaimana perbandingan pengetahuan, pemahaman dan implementasi nelayan pribumi dan nelayan pendatang terhadap Awig-awig yang kehidupan masyarakat nelayan?

3. Bagaimana efektivitas Awig-awig dalam pengaturan kehidupan masyarakat nelayan?

\section{Tujuan Penelitian}

Tujuan penelitian dirumuskan sebagai berikut:

1. Mengetahui bentuk Awig-awig yang mengatur kehidupan masyarakat nelayan.

2. Menganalisis perbandingan pengetahuan, pemahaman dan implementasi nelayan pribumi dan nelayan pendatang terhadap Awig-awig yang mengatur kehidupan masyarakat nelayan.

3. Menganalisis efektivitas Awig-awig dalam pengaturan kehidupan masyarakat nelayan 


\section{Kegunaan Penelitian}

Penelitian ini memiliki kegunaan sebagai berikut:

1. Bagi akademisi, penelitian ini diharapkan dapat menjadi bahan referensi dan kajian untuk penelitian selanjutnya serta menambah khasanah penelitian mengenai efektivitas Awig-awig dalam pengaturan kehidupan masyarakat nelayan.

2. Bagi masyarakat, penelitian ini dapat membantu masyarakat untuk mengambil manfaat dari hasil penelitian yang dilakukan penulis.

3. Bagi pemerintah, penelitian ini diharapkan dapat menjadi bahan pertimbangan untuk program-program pemerintah dalam melakukan usaha pelestarian lingkungan pesisir.

\section{TINJAUAN PUSTAKA}

\section{Kelembagaan}

Menurut Djogo et al, (2003), kelembagaan adalah suatu tatanan dan pola hubungan antara anggota masyarakat atau organisasi yang saling mengikat yang dapat menentukan hubungan antar manusia atau antar organisasi yang diwadahi dalam suatu organisasi atau jaringan dan ditentukan oleh faktor-faktor pembatas dan pengikut berupa norma, kode etik aturan formal maupun informal untuk pengendalian perilaku sosial serta intensif untuk bekerja sama dan mencapai tujuan bersama. Menurut Uphoff (1993) dalam Soekanto (2009), kelembagaan adalah seperangkat norma yang bertahan dari waktu ke waktu dengan memenuhi kebutuhan kolektif.

Menurut Djogo et al, (2003), kelembagaan mempunyai beberapa unsur penting

a) Institusi merupakan landasan untuk membangun tingkah laku sosial masyarakat

b) Norma tingkah laku yang mengakar dalam masyarakat dan diterima secara luas untuk melayani tujuan bersama yang mengandung nilai tertentu dan menghasilkan interaksi antar manusia yang terstruktur

c) Peraturan dan penegakan aturan/hukum

d) Aturan dalam masyarakat yang memfasilitasi koordinasi dan kerjasama dengan dukungan tingkah laku, hak dan kewajiban anggota

e) Kode etik

f) Kontrak

g) Pasar

h) Hak milik

i) Organisasi

j). Intensif untuk menghasilkan tingkah laku yang diinginkan

Menurut Nasution et al (2007) kelembagaan yang terbentuk di masyarakat adalah dilatarbelakangi berupa pola-pola kepemimpinan lokal yang mengikuti pola-pola kesukuan dan bersifat informal. Artinya masing-masing suku biasanya memiliki pemimpin lokal sendiri.

\section{Kelembagaan Sosial}

Kelembagaan sosial sering diartikan sebagai pranata sosial.
Menurut Koentjaraningrat (1990), pranata sosial adalah sistem kelakuan dan hubungan yang berpusat kepada aktivitas-aktivitas untuk memenuhi kompleks-kompleks kebutuhan khusus dalam kehidupan masyarakat. Pranata sosial menunjuk pada adanya unsur-unsur yang mengatur perilaku warga masyarakat. Dalam sosiologi, kelembagaan sosial adalah suatu kompleks atau sistem peraturanperaturan dan adat istiadat yang mempertahankan nilainilai yang penting.

Kelembagaan sosial pada dasarnya menyangkut seperangkat norma atau tata laku. Menurut Doorn dan Lammers (1959), fungsi kelembagaan sosial :

1. Memberi pedoman berperilaku pada individu/ masyarakat: bagaimana mereka harus bertingkah laku atau bersikap di dalam menghadapi masalah-masalah dalam masyarakat, terutama yang menyangkut kebutuhan-kebutuhan

2. Menjaga keutuhan: dengan adanya pedoman yang diterima bersama, maka kesatuan dalam masyarakat dapat terpelihara

3. Memberi pegangan kepada masyarakat untuk mengadakan kontrol sosial (social control): artinya sistem pengawasan masyarakat terhadap tingkah laku anggotanya dan

4. Memenuhi kebutuhan pokok manusia/masyarakat

Menurut Soekanto (1990), ciri-ciri yang membedakan kelembagaan dari konsepsi-konsepsi lain seperti grup, asosiasi, dan organisasi lainnya adalah sebagai berikut :

- Merupakan pengorganisasian pola pemikiran dan perilaku yang terwujud melalui aktivitas masyarakat dan hasil-hasilnya.

- Memiliki kekekalan tertentu: perkelembagaan suatu norma memerlukan waktu yang lama karena itu cenderung dipertahankan.

- Mempunyai satu atau lebih tujuan tertentu.

- Mempunyai lambang-lambang yang secara simbolik menggambarkan tujuan

- Mempunyai alat untuk mencapai tujuan tertentu.

- Mempunyai tradisi tertulis atau tidak tertulis.

Menurut Tahir dan Wasistiono (2007), Kelembagaan lokal merupakan pranata sosial tingkat lokal yang berdiri antara individu dalam kehidupan pribadinya dengan lingkungan, yang ternyata tidak hanya berperan mengatur tata kehidupan masyarakat saja, akan tetapi juga mempunyai peranan sangat penting bagi pertumbuhan ekonomi suatu masyarakat.

Menurut Setiadi et al, (2011), norma adalah pola-pola sesuatu yang menjadi pedoman untuk mencapai tujuan dari kehidupan sosial yang didalamnya terdapat seperangkat perintah dan larangan berupa sanksi. Aturan lokal terbentuk berdasarkan nilai-nilai dan norma-norma yang berlaku pada masyarakat. Secara konseptual ada empat tingkat norma yaitu cara, kebiasaan, tata kelakuan dan adat istiadat. Perincian keempat tingkatan norma tersebut adalah sebagai berikut :

1. Cara (usage): lebih menonjol di dalam hubungan antarindividu dalam masyarakat atau menunjuk pada suatu bentuk perbuatan. Suatu penyimpangan terhadapnya, 
secara moral dirasakan sebagai sesuatu yang tidak pantas oleh pelakunya. Penyimpangan tersebut oleh masyarakat hanya dinilai sebagai suatu perbuatan yang dianggap janggal.

2. Kebiasaan (folkways): mempunyai kekuatan mengikat yang lebih besar dibandingkan cara. Bagi yang melanggar kebiasaan tersebut, secara moral akan merasa malu dan akan dicela oleh masyarakat di sekitarnya.

3. Tata kelakuan (mores): merupakan kebiasaan yang dianggap sebagai cara berperilaku dan diterima sebagai norma-norma pengatur. Orang-orang yang melanggar tingkatan norma tata-kelakuan, secara moral akan merasa bersalah. Di samping itu, pelanggar akan dihukum oleh masyarakat sekitar.

4. Adat istiadat (customs): merupakan tata kelakuan yang kekal serta kuat intergrasinya dengan pola-pola perilaku masyarakat. Bila adat istiadat dilanggar, secara moral pelanggar akan merasa berdosa. Kemudian masyarakat akan mengeluarkan pelakunya dari komunitasnya. Dengan kata lain, sanksinya berwujud suatu pederitaan bagi pelanggarnya.

Awig-awig merupakan salah satu contoh kelembagaan lokal yang berada di daerah Bali dan Lombok. Awig-awig berasal dari kata wig yang artinya rusak sedangkan awig artinya tidak rusak atau baik. Awig-awig artinya adalah sesuatu yang menjadi baik. Awig-awig berisi aturan-aturan, baik tertulis maupun tidak tertulis yang dibuat oleh masyarakat dengan tujuan mengatur tata tertib kehidupan sehari-hari (Husni 2002 dalam Saba 2003). Awig-awig sebagai salah satu bentuk dari hukum adat di Bali, merupakan hukum yang hidup yang dibuat oleh masyarakat adat sebagai pedoman bertingkah laku dalam pergaulan hidup bermasyarakat (Astiti et al, 2011). Menurut Suasthawa (2001), desa adat merupakan hukum adat yang mempunyai fungsi untuk mengatur dan mengendalikan perilaku warga masyarakat dalam pergaulan hidupnya guna mencapai ketertiban dan ketentraman masyarakat. Selain itu Awig-awig juga berfungsi untuk mengintegrasikan warga masyarakat dalam suatu persatuan dan kesatuan yang hidup bersama sepenanggungan dan seperjuangan.

Menurut Astiti et al, 2011, Hukum adat Bali (Awig-awig) mempunyai kekhususan antara lain terkait dengan filosofi, asas-asas dan sanksi serta cara-cara penyelesaian sengketa. Awig-awig mengandung filosofi Tri Hita Karana. Ajaran Tri Hita Karana adalah salah satu ajaran pada agama hindu yang pada intinya mengajarkan tentang keseimbangan antara manusia dengan Tuhan, manusia dengan manusia dan manusia dengan lingkungannya. Masyarakat Bali menganggap kebahagiaan akan tercapai jika tiga keseimbangan dari Tri Hita Karana dapat terwujud. Konsep dari Tri Hita Karana adalah bahwa manusia hidup sesuai dengan kodratnya senantiasa mangandung unsur untuk mencapai kebahagiaan. Didalam memenuhi tuntutan hidupnya itu manusia senantiasa tergantung pada manusia lain. Hubungan manusia dengan alam dimana ia hidup berpijak menimbulkan rasa cinta pada tanah tumpah darahnya.

Menurut Astiti et al. (2011), Awig-awig yang berisi sekumpulan aturan tersebut mempunyai sanksi-sanksi bagi yang melanggar. Sanksi tersebut ada beberapa jenis antara lain sanksi melaksanakan kewajiban (ayahan), membayar sejumlah uang (danda), minta maaf (pangampura), membuat upacara, pangucilan (kasepekang) dan dipecat sebagai krama. Jika ditinjau dari filosofi Tri Hita Karana, maka penerapan sanksi-sanksi tersebut terkait dengan tiga keseimbangan yang diajarkan dalam Tri Hita Karana. Sanksi berupa pelaksanaan upacara itu berkaitan dengan unsur hubungan manusia dengan Tuhan. Sanksi permintaan maaf dan ayahan dapat dikatakan terkait dengan unsur hubungan manusia dengan manusia. Ketiga sanksi tersebut mengacu pada hubungan keharmonisan antara manusia dengan Tuhan serta manusia dengan manusia. Berbeda dengan sanksi pangucilan dan dipecat sebagai krama. Keduanya tergolong sanksi yang berkaitan dengan hubungan manusia dan manusia namun tidak mencerminkan adanya keharmonisan karena bersifat menjauhkan seseorang atau sekelompok warga dari warga lain. Aturan-aturan dalam Awig-awig tersebut dapat ditambah dan dikurangi. Itu berarti Awig-awig dapat diubah untuk disempurnakan. Pada Awig-awig dalam pengaturan kehidupan masyarakat nelayan di Pantai Kedonganan, masing-masing aturan mempunyai tingkat norma yang berbeda-beda.

\section{Masyarakat Nelayan}

Nelayan dapat didefinsikan sebagai orang yang secara aktif melakukan pekerjaan dalam operasi penangkapan ikan/binatang air lainnya/tanaman air. Orang yang hanya melakukan pekerjaan seperti membuat jaring, mengangkut alat-alat perlengkapan ke dalam perahu/kapal, tidak dimasukkan sebagai nelayan. Sementara masyarakat nelayan adalah kelompok atau sekelompok orang yang bekerja sebagai nelayan, nelayan kecil, pembudi daya ikan kecil yang bertempat tinggal di sekitar kawasan nelayan (Peraturan Menteri Perumahan Rakyat No. 15/ Permen/M/2006). Seiring dengan perkembangan sektor perikanan, pelaku penangkapan ikan menjadi beragam statusnya karena adanya diferensiasi sosial. Masyarakat nelayan biasanya tinggal di daerah dekat laut dan memilki hubungan erat berdasarkan kekeluargaan.

Menurut Satria (2002), berdasarkan status penguasaan kapital nelayan dapat dibagi menjadi nelayan pemilik dan nelayan buruh. Nelayan pemilik atau juragan adalah orang yang memiliki sarana penangkapan seperti kapal, jaring dan alat tangkap ikannya. Sementara nelayan buruh adalah orang yang menjual jasa tenaga kerja sebagai buruh dalam kegiatan penangkapan ikan di laut atau sering disebut sebagai Anak Buah Kapal (ABK)

Menurut Satria (2002), nelayan dapat digolongkan berdasarkan kapasitas teknologi, orientasi pasar dan karakteristik hubungan produksi. Pembagian kelompok nelayan sebagai berikut :

Peasant-fisher atau nelayan tradisional yang biasanya lebih berorientasi ada pemenuhan kebutuhan sendiri. Alokasi hasil tangkapan yang dijual lebih banyak untuk memenuhi kebutuhan sehari-hari (khusus pangan) dan bukan diinvestasikan untuk pengembangan usaha. Alat tangkap yang digunakan masih tradisional, tanpa motor dan melibatkan anggota keluarga sebagai tenaga kerja utama.

1. Post-peasant fisher yaitu nelayan yang telah menggunakan teknologi penangkapan yang lebih maju seperti motor tempel atau kapal motor. Orientasi pasar sudah sangat terasa dan pekerjaan dilakukan dengan menggunakan tenaga kerja (ABK) dan tidak 
bertanggung pada anggota keluarga saja

2. Commercal fisher yaitu yang berorientasi pada peningkatan keuntungan. Teknologi penangkapan yang digunakan lebih modern dan memperkerjakan tenaga kerja lebih banyak dengan pembagian kerja yang jelas

3. Industrial fisher yaitu nelayan yang memiliki usaha penangkapan yang bersifat pada modal dan dikelola secara modern dan memiliki orientasi eskpor

Terbatasnya sumber daya alam untuk kegiatan penangkapan ikan, maka di Indonesia didominasi oleh nelayan peasantfisher dan post-peasant fisher. Menurut Satria (2002), Penggolongan nelayan juga dapat dilakukan berdasarkan waktu yang digunakan untuk melakukan pekerjaan operasi penangkapan, antara lain :

1. Nelayan ikan penuh, yaitu orang yang seluruh waktu kerjanya digunakan untuk melakukan pekerjaan operasi penangkapan atau pemeliharaan ikan

2. Nelayan ikan sambilan, yaitu orang yang sebagian besar waktu kerjanya digunakan untuk melakukan pekerjaan operasi penangkapan atau pemeliharaan ikan.

3. Nelayan ikan sambilan tambahan, yaitu orang yang sebagian kecil waktu kerjanya digunakan untuk melakukan pekerjaan penangkapan atau pemeliharaan ikan.

\section{Wilayah Pesisir}

Menurut kesepakatan internasional, wilayah pesisir didefinisikan sebagai wilayah peralihan antara daratan, ke arah darat mencakup daerah yang masih terpengaruh percikan air laut atau pasang surut, dan ke arah laut meliputi daerah paparan benua. Menurut Dahuri et al. (2004), hingga saat ini belum ada definisi pesisir yang baku. Namun demikian, terdapat kesepakatan di dunia bahwa wilayah pesisir adalah suatu wilayah peralihan antara daratan dan lautan. Apabila ditinjau dari garis pantai (coast line), maka wilayah pesisir mempunyai dua macam batas (boundaries) yaitu batas yang sejajar garis pantai (long shore) dan batas yang tegak lurus garis pantai (cross shore). Menurut Dahuri et al. 2004, Wilayah pesisir merupakan ekosistem yang dinamis dan mempunyai kekayaan habitat yang beragam, serta saling berinteraksi antar habitat tersebut. Selain mempunyai potensi yang besar, wilayah pesisir juga merupakan ekosistem yang paling mudah terkena dampak kegiatan manusia. Pengelolaan pesisir baik secara langsung maupun tidak langsung harus memperhatikan keterkaitan ekologis antar ekosistem di wilayah pesisir.

Menurut Dahuri et al. 2004, wilayah pesisir dapat dikembangkan untuk kegiatan pembangunan seperti pengembangan kawasan pemukiman dipesisir, pengembangan lahan pertambakan, kegiatan pengilangan minyak di wilayah pesisir, kegiatan reklamasi di wilayah pesisir, kegiatan industri yang dikembangkan di wilayah pesisir, kegiatan pariwisata dan bahari, serta kegiatan pertanian dan perkebunan di lahan atas.

Menurut Dahuri et al.(2004), wilayah pesisir memiliki tiga ciri karakteristik unik dari ekosistem pesisir yang membuat pengelolaannya lebih menantang (challenging) dibandingkan dengan pengelolaan ekosistem di darat maupun di laut lepas (high seas). Ketiga ciri tersebut yaitu sistem lingkungan alam yang kompleks, pemanfaatan yang beragam dan kepemilikan.

\section{Pengelolaan Sumber Daya Alam Pesisir}

Menurut Afiati (1999), pengelolaan sumberdaya alam adalah usaha manusia dalam mengubah ekosistem untuk memperoleh manfaat maksimal, dengan mengupayakan kesinambungan produksi dan menjamin kelestarian sumberdaya tersebut. Menurut Dahuri et al. (2004), Pengelolaan wilayah pesisir memerlukan suatu pengelolaan yang tepat dan terpadu baik bagi sumber daya alam maupun masyarakatnya. Keterpaduan pengelolaan wilayah pesisir ini mencakup empat aspek yaitu keterpaduan wilayah/ ekologis, keterpaduan sektor, keterpaduan disiplin ilmu dan keterpaduan stakeholders.

Dalam pemanfaatan sumberdaya pesisir, aspek ekologis dalam hal kelestarian sumberdaya dan fungsi-fungsi ekosistem harus dipertahankan. Pengelolaan sumberdaya pesisir pada dasarnya bertujuan untuk meningkatkan kesejahteraan terutama kesejahteraan komunitas masyarakat lokal yang bermukim di wilayah pesisir. Pemanfaatan sumberdaya pesisir diharapkan tidak menyebabkan rusaknya fishing ground, spawning ground maupun nursey ground ikan. Undang-Undang no 27 tahun 2007 tentang pengelolaan pesisir dan pulau-pulau kecil telah mempertimbangkan keberadaan masyarakat adat dalam pengelolaan sumberdaya pesisir dan pulau-pulau kecil. Menurut Sumardjono (2008), masyarakat adat adalah sekelompok masyarakat pesisir yang secara turun-temurun bermukin di wilayah geografis tertentu karena adanya ikatan pada asal-usul leluhur, adanya hubungan yang kuat dengan sumberdaya pesisir dan pulau-pulau kecil serta adanya sistem nilai yang menentukan pranata ekonomi, politik, sosial dan hukum. Dalam pasal 12 UU No. 27/2007 dijelaskan bahwa masyarakat adat diberikan hak untuk memilki Hak Pengusahaan Perairan Pesisir (HP-3).

Menurut Nikijuluw (1994) dalam Stanis (2007), pengelolaan berbasis masyarakat atau biasa disebut Community Based Management merupakan pendekatan pengelolaan sumberdaya alam yang meletakkan pengetahuan dan kesadaran lingkungan masyarakat lokal sebagai dasar pengelolaannya. Selain itu mereka juga memiliki akar budaya yang kuat dan biasanya tergabung dalam kepercayaannya (religion). Pengelolaan berbasis masyarakat adalah suatu strategi untuk mencapai pembangunan yang berpusat pada manusia, di mana pusat pengambilan keputusan mengenai pemanfaatan sumberdaya secara berkelanjutan di suatu daerah berada di tangan organisasi-organisasi dalam masyarakat daerah tersebut. Pantai kedonganan pengelolaannya berbasis masyarakat atau biasa disebut Community Based Management .

\section{Konsep Perilaku}

Seperti yang dikutip pada modul belajar Ilmu Penyuluhan, seorang ahli pendidikan yaitu Bloom dan rekan-rekannya mengembangkan klasifikasi hasil belajar yang disebut taksonomi Bloom. Para ahli tersebut mecoba merumuskan taksonomi di tiga ranah perilaku yaitu ranah kognitif, afektif dan psikomotrik. Pada studi ini akan mempelajari perilaku nelayan pada ranah kognitif. Pada ranah kognitif terdiri dari tahap pengetahuan, pemahaman, penerapan, analisa, sintesa dan evaluasi. Namun pada penelitian ini akan menganalisis sampai tahap penerapan atau implementasi 
saja untuk melihat efektivitas Awig-awig dalam mengatur perilaku nelayan.

Efektivitas dalam mengatur perilaku tersebut dilihat dari jumlah individu yang mentaati dan yang melanggar aturan. Tahap pengetahuan meliputi informasi yang disimpan dalam ingatan manusia dan digali pada saat dibutuhkan melalui bentuk ingatan mengingat (recall) atau mengenal kembali. Selanjutnya pada tahap pemahaman, individu mempunyai kemampuan untuk menangkap makna dan arti dari berbagai hal yang pernah dilakukan dan dipelajarinya pada kondisi kongkrit dan baru. Tahap penerapan merupakan kemampuan individu itu menerapkan atau mengimplementasikan apa yang telah dipelajari. Kemampuan ini setingkat lebih tinggi daripada kemampuan sebelumnya karena memahami suatu kaidah belum tentu membawa kemampuan untuk menerapkannya terhadap suatu kasus atau problem baru.

\section{Kerangka Pemikiran}

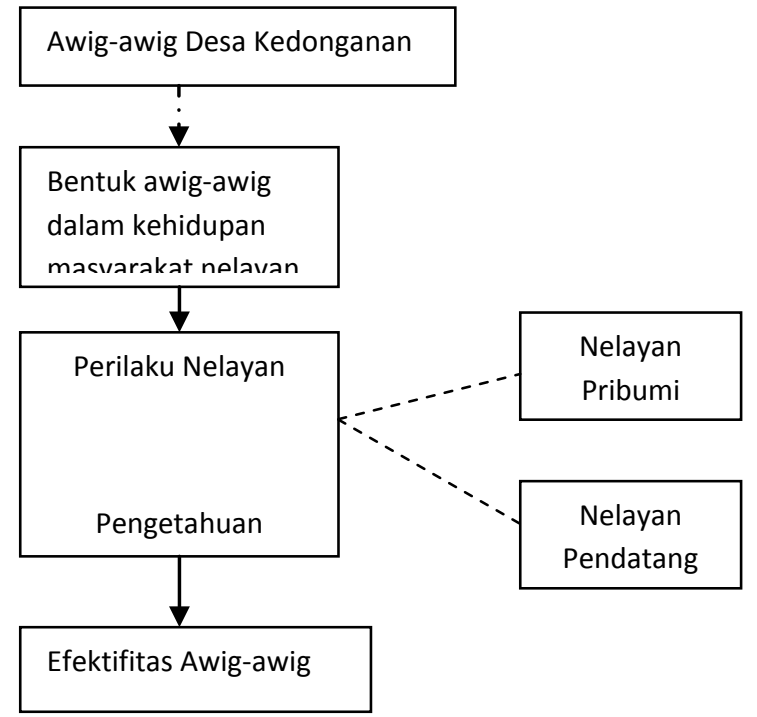

Keterangan :

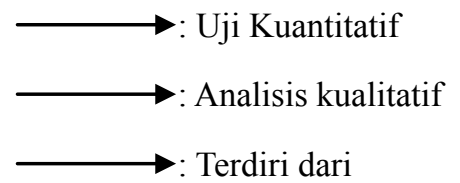

Awig-awig merupakan sekumpulan aturan lokal yang dibuat berdasarkan kesepakatan masyarakat bersama untuk mengatur perilaku sehari-hari dalam bermasyarakat. Awigawig berbentuk aturan tertulis maupun tidak tertulis yang mengatur berbagai aspek kehidupan masyarakat. Sejak dahulu, Desa Kedonganan dikenal sebagai desa nelayan karena mayoritas penduduknya bekerja sebagai nelayan dan wilayahnya yang berada di sekitar Pantai Kedonganan. Nelayannya pun masih banyak yang memakai alat tangkap dan jukung tradisional. Untuk mengatur perilaku nelayan, maka diberlakukan pula Awig-awig mengenai pengaturan kehidupan masyarakat nelayan khususnya dalam pengaturan penangkapan ikan. Awig-awig yang dibuat atas kesepakatan tokoh masyarakat, ketua nelayan dan beberapa nelayan setempat ini sudah ada sejak dulu namun ada yang mengalami beberapa perubahan karena menyesuaikan dengan perkembangan zaman. Aturan dalam Awig-awig tersebut mempunyai tingkatan norma yang berbeda dan mempunyai sanksi sebagai wujud kontrol sosial.

Dalam penelitian ini akan menganalisis perilaku nelayan terhadap Awig-awig tersebut yang dilihat dari aspek pengetahuan, pemahaman dan implementasi mereka. Pengetahuan meliputi apakah mereka mengetahui adanya aturan tersebut atau tidak. Pemahaman meliputi apakah nelayan memahami isi dan tujuan dari aturan tersebut atau tidak. Sementara itu, implementasi meliputi apakah nelayan mengimplementasikan aturan tersebut atau melanggarnya. Nelayan yang melaut di Pantai Kedonganan tidak hanya nelayan pribumi yang berasal dari Desa Kedonganan atau yang berasal dari Pulau Bali tetapi juga terdapat nelayan pendatang yang berasal dari berbagai daerah. Baik nelayan pribumi maupun nelayan pendatang harus mentaati Awigawig yang berlaku. Untuk itu responden dalam penelitian ini adalah nelayan pribumi dan nelayan pendatang. Nelayan pribumi sebagai orang yang lekat dengan kebudayaan Bali dan memeluk Agama Hindu tentu sudah tidak asing lagi dengan Awig-awig yang dibuat berlandaskan filosofi ajaran Agama Hindu yaitu Tri Hita Karana.

Sedangkan nelayan pendatang berasal berbagai daerah yang mempunyai latar belakang budaya dan agama yang berbeda. Nelayan pendatang cenderung membawa budaya nya masing-masing. Efektivitas Awig-awig dalam mengatur perilaku nelayan dapat terlihat dari jumlah pelanggaran yang dilakukan oleh nelayan. Selain itu juga dapat dianalisis faktor-faktor keefektivitasan tersebut seperti bentuk sosialisasi, petugas, sanksi dan kesadaran nelayan.

\section{Hipotesis Penelitian}

Hipotesis penelitian ini disajikan sebagai berikut:

1. Diduga terdapat perbedaan tingkat pengetahuan, pemahaman dan implementasi Awig-awig antara nelayan pribumi dan nelayan pendatang.

2. Diduga tingkat efektivitas dalam mengatur perilaku nelayan pribumi lebih tinggi karena mereka lebih mentaati adat setempat dan ajaran agama hindu dibandingkan nelayan pendatang.

\section{Metode Penelitian}

Pada penelitian ini menggunakan metode penelitian kualitatif dan metode penelitian kuantitatif. Metode penelitian kualitatif dilakukan melalui observasi dan wawancara mendalam kepada tokoh masyarakat desa, ketua kelompok nelayan dan nelayan kedonganan. Metode kualitatif digunakan untuk mengetahui bentuk norma dan adat Desa Kedonganan, bentuk kelembagaan lokal, tujuan dibentuknya kelembagaan lokal, wujud kontrol sosial dan sosialisasi Awig-awig serta untuk mendukung metode kuantitatif. Metode kuantitatif dilakukan dengan penelitian survei menggunakan instrumen kuesioner dengan mengambil sampel dari satu populasi. Metode kuantitatif dalam penelitian ini digunakan untuk meneliti beberapa variabel seperti karakteristik nelayan (usia, agama, asal daerah, lama bekerja sebagai nelayan, pekerjaan sampingan dan status penguasaan kapital), perilaku nelayan (pengetahuan, pemahaman dan implementasi) serta bentuk sosialisasi yang paling efektif bagi nelayan.

Pendekatan yang dilakukan dalam penelitian ini adalah 
penelitian deskriptif yang dibuat untuk penjelasan secara sistematis, faktual, dan akurat mengenai fakta-fakta dan sifat-sifat populasi atau daerah tertentu. Selain itu selama penelitian ini juga dilakukan pengujian hipotesa yang telah dirumuskan sebelumnya.

\section{Lokasi dan Waktu}

Penelitian ini dilakukan di sekitar Pantai Kedonganan yang terdapat di sebelah utara Pulau Bali. lokasi ini terletak di Desa Kedonganan, Kecamatan Kuta Kabupaten Badung. Penentuan lokasi penelitian dilakukan secara sengaja (purpose) dengan pertimbangan karena adanya karakterisitik yang sesuai dengan penelitian. Karakteristik tersebut yaitu Pantai Kedonganan merupakan pantai yang pengelolaannya diserahkan kepada masyarakat adat.

Hal ini menunjukkan terdapatnya kelembagaan lokal khususnya dalam mengatur kehidupan masyarakat nelayan. Pantai kedonganan juga terkenal dengan pantai yang masih terdapat banyak nelayan tradisional baik nelayan asli daerah tersebut maupun nelayan pendatang dari luar daerah. Kelembagaan lokal tersebut dikenal dengan nama Awig-awig yang berisi sekumpulan aturan adat yang berdasarkan nilai, pengetahuan dan kearifan lokal beserta sanksi nya.

\section{Teknik Pengumpulan Data}

Data yang digunakan dalam penelitian ini adalah data primer dan data sekunder. Data primer diperoleh dari kuesioner dan wawancara mendalam. Kuesioner dibagikan kepada responden. Sedangkan wawancara mendalam dilakukan dengan menggunakan panduan pertanyaan kepada informan maupun responden. Responden dalam penelitian ini adalah nelayan yang biasa menangkap ikan di Pantai Kedonganan Bali.Kemudian dilakukan cluster sampling yaitu nelayan pribumi dan nelayan pendatang. Unit analisis dalam penelitian ini adalah individu. Penentuan pengambilan responden dilakukan dengan penentuan jumlah responden yaitu dengan mengumpulkan data jumlah nelayan pribumi dan nelayan pendatang. Jumlah keseluruhan populasi nelayan yang didapat sebanyak 135 orang.

Populasi sasaran nelayan pribumi sebanyak 65 orang dan nelayan pendatang sebanyak 70 orang. Jumlah populasi nelayan pribumi didapatkan dari data kelompok nelayan dan jumlah populasi nelayan pendatang diperoleh dari hasil penelusuran lapang yaitu mendata beberapa nelayan pendatang yang melaut di Pantai Kedonganan dan bekerja sebagai nelayan di kedonganan minimal enam bulan. Setelah diperoleh data populasi nelayan pribumi dan nelayan pendatang, lalu diambil masing-masing 30 orang nelayan pribumi dan 30 orang nelayan pendatang untuk dijadikan responden dengan menggunakan metode pengambilan data acak sederhana (simple random sampling) yaitu sebuah sampel yang diambil sedemikian rupa setiap unit penelitian atau satuan elementer dari populasi mempunyai kesempatan yang sama untuk dipilih sebagai sampel. Pengambilan data acak sederhana menggunakan microsoft excel 2010.

Pemilihan informan dilakukan secara purposive dan tidak ditentukan jumlahnya informan kunci yang dipilih adalah perangkat desa adat yang mengelola kawasan Pantai Kedongan serta mengetahui dan memahami secara mendalam mengenai Awig-awig dalam kegiatan penangkapan ikan, ketua kelompok nelayan dan nelayan.
Data sekunder diperoleh dari buku penelitian, laporan penelitian, skripsi, tesis, serta jurnal dan karya ilmiah melalui internet yang berkaitan dengan tujuan penelitian

\section{Teknik Pengolahan dan Analisis Data}

Data kuantitatif diperoleh melalui penyebaran kuesioner di lapangan yang diperkuat dengan teknik wawancara langsung dengan responden. Data kuantitatif digunakan untuk menggambarkan seperti karakteristik nelayan (usia, agama, asal daerah, lama bekerja sebagai nelayan, pekerjaan sampingan dan status penguasaan kapital), perilaku nelayan terhadap Awig-awig (pengetahuan, pemahaman dan implementasi) serta bentuk sosialisasi yang diperoleh nelayan. Dalam pengolahan kuantitatif, data dibagi menjadi dua yaitu data nelayan pribumi dan data nelayan pendatang untuk dilihat perbandingan antar keduanya. Pengelolahan data kuantitatif pada penelitian ini mengacu pada langkah-langkah pengolahan dari Effendi et al. (1989) yaitu Pertama, memasukkan data ke dalam kartu atau berkas data. Kedua, membuat Tabel frekuensi atau Tabel silang. Ketiga, mengoreksi kesalahan-kesalahan yang ditemui setelah membaca Tabel frekuensi atau Tabel silang. Kemudian data yang sudah dikumpulkan akan diolah menggunakan microsoft excel 2010 untuk menghitung jawaban responden dalam bentuk Tabel frekuensi.

Data kualitatif diperoleh dari wawancara mendalam terhadap informan dan wawancara langsung dengan responden. Hasil wawancara tersebut ditulis dalam catatan harian secara sistematis. Data kualitatif akan diolah melalui tiga tahapan. Pertama, reduksi data yang bertujuan untuk merangkum, memilih hal-hal pokok, memfokuskan pada hal-hal penting dan membuang data-data yang tidak diperlukan. Kedua, penyajian data yaitu data yang berbentuk teks naratif seperti pada catatan harian dibuat dalam bentuk matriks seperti bentuk pengaturan dalam Awig-awig, sanksi yang diterapkan, penghargaan yang diberikan, bentuk sosialisasi yang dilakukan dan faktorfaktor yang menyebabkan nelayan melakukan pelanggaran. Hal ini mempermudah peneliti dalam mengorganisir dan memahami data. Ketiga, penarikan kesimpulan yaitu menghasilkan temuan baru atas objek penelitian dan atas hasil analisis data yang diperoleh.

Dalam mengukur tingkat pengetahuan, pemahaman dan implementasi akan disediakan masing-masing 7 pertanyaan mengenai masing-masing aturan dalam Awigawig yang berkaitan dengan pengetahuan, pemahaman dan implementasi responden. Akan disediakan jawaban YA dan TIDAK. Jawaban YA akan diberi indeks 2 dan jawaban TIDAK akan diberi indeks 1. Pengetahuan meliputi apakah responden mengetahui atau tidak mengetahui aturan tersebut dan dapat mengingat kembali informasi yang didapat. Pemahaman meliputi memahami atau tidak memahami aturan-aturan tersebut serta nelayan dapat menjelaskan bentuk peraturannya, makna dari aturan tersebut, tujuan dari aturan tersebut dan dapat menjelaskan contoh-contohnya. Sedangkan implementasi meliputi apakah responden menerapkan atau tidak menerapkan aturan lokal tentang pengaturan kehidupan masyarakat nelayan yang terdapat di Pantai Kedonganan Bali.

Efektivitas Awig-awig dalam mengatur perilaku nelayan dapat dilihat dari jumlah pelanggaran. Tingkat efektivitas Awig-awig dalam mengatur perilaku nelayan dapat digolongkan menjadi tingkat pelanggaran rendah dan 
tingkat pelanggaran tinggi. Tingkat pelanggaran rendah berada dalam kategori aman jika jumlah pelanggaran dalam rentang $0 \%-24 \%$. Tingkat pelanggaran rendah dalam kategori pelanggaran kurang serius jika jumlah pelanggaran dalam rentang $25 \%$ sampai $49 \%$. Tingkat pelanggaran tinggi berada pada kategori pelanggaran serius jika jumlah pelanggaran dalam rentang 50\% sampai $74 \%$ dan kategori pelanggaran sangat serius jika jumlah pelanggaran dalam rentang $75 \%$ sampai $100 \%$.

\section{GAMBARAN UMUM}

\section{Kondisi Geografis}

Desa Kedonganan merupakan salah satu desa yang berada di Kecamatan Kuta, Kabupaten Badung. Topografi Desa Kedonganan merupakan dataran rendah dengan tinggi tempat dari permukaan laut $43 \mathrm{mdl}$. Desa ini memiliki curah hujan $1700 \mathrm{Mm}$ dan suhu rata-rata harian 23.5 $25 \mathrm{C}$. Wilayah desa kedonganan terletak di tepi pantai atau pesisir Desa Kedonganan memiliki luas wilayah sekitar 190.75 ha dan memiliki batas-batas wilayah

$\begin{array}{lll}\text { - } & \text { Sebelah Utara } & \text { : Kelurahan Tuban } \\ \text { - } & \text { Sebelah Selatan } & \text { : Kelurahan Jimbaran } \\ \text { - } & \text { Sebelah Timur } & \text { : Selat Badung } \\ \text { Sebelah Barat } & \text { : Samudera Indonesia }\end{array}$

Desa Kedonganan merupakan desa administratif (desa dinas) yang memiliki enam dusun yaitu Dusun Kubu Akit, Dusun Ketapang, Dusun Anyar Gede, Dusun Pasek, Dusun Kerthayasa dan Dusun Pengenderan. Adapun jarak menuju ibukota kecamatan $5 \mathrm{Km}$, jarak ke ibukota kabupaten 26 $\mathrm{Km}$ dan jarak ke ibu kota provinsi $20 \mathrm{Km}$.

\section{Kondisi Ekonomi}

Desa Kedonganan terkenal sebagai desa nelayan karena mayoritas penduduknya bermata pencaharian sebagai nelayan. Namun seiring berjalannya waktu, jumlah nelayan semakin berkurang dan muncul sektor-sektor baru di Desa Kedonganan yang menjadi mata pencaharian penduduk. Desa Kedonganan menitikberatkan pada sektor industri menengah dan besar. Meskipun sektor perikanan sudah bukan menjadi sektor utama, namun jumlah produksi perikanan masih cukup tinggi dan masih menjadi potensi perkembangan desa yang sangat potensial disamping pariwisata dengan indikator unggulan wisata kuliner seafood dan program minapolitan.

Komoditi perikanan yang menjadi andalan nelayan Desa Kedonganan adalah ikan tuna yang jumlah produksi nya mencapai 9005.5 ton pertahun, ikan tongkol sebesar 1478.5 ton pertahun dan ikan sarden 547.1 ton pertahun. Nelayan kedonganan mayoritas masih menggunakan alat tradisional dalam menangkap ikan seperti perahu tradisional, jala dan pancing. Sektor ekonomi yang menonjol dan menjadi andalan selain sektor industri menengah dan besar adalah sektor industri kecil. Pada sektor jasa yang berkembang cukup pesat termasuk di dalamnya adalah usaha jasa transportasi dan perhubungan serta usaha rumah makan atau restaurant. Pada sektor industri kecil yang paling menonjol adalah kerajinan kayu, kerajinan batu dan kerajinan anyaman.

\section{Kondisi Sosial}

Data yang diperoleh pada tahun 2010, menunjukkan jumlah peduduk Desa Kedonganan sebanyak 5037 orang yang terdiri dari 2500 orang perempuan dan 2537 orang lakilaki. Jumlah kepala keluarga sebanyak $1075 \mathrm{kk}$ dengan kepadatan penduduk 2637 per km2. Jumlah penduduk menurut penggolongan usia dapat dirinci sebagai berikut :

- Penduduk usia 0-6 tahun : 50 orang

- Penduduk usia 7-18 tahun yang masih sekolah : 851 orang

- $\quad$ Penduduk usia 18-56 tahun yang bekerja: 3360 orang

- Penduduk usia 56 tahun ke atas : 776 orang

\section{Tingkat Pendidikan Masyarakat}

Desa Kedonganan memberikan dukungan penuh agar dapat meningkatkan kualitas pendidikan masyarakat. Seperti memberikan sarana dan prasarana pendidikan yaitu gedung sekolah TK, SD, SMP dan SMA serta gedung tempat bermain anak dan perpustakaan desa. Penduduk Desa Kedonganan mayoritas memiliki tingkat pendidikan sampai Sekolah Dasar (SD).

\section{Struktur Mata Pencaharian Penduduk}

Mata pencaharian dapat secara langsung mempengaruhi kondisi ekonomi masyarakat Desa Kedonganan. Beberapa masyarakat ada yang mempunyai pekerjaan di luar wilayah Desa Kedonganan. Hal ini karena daya dukung sektorsektor di Desa Kedonganan ada yang tidak sesuai dengan kemampuan dan keinginan beberapa masyarakat. Struktur mata pencaharian penduduk Desa Kedonganan mayoritas bekerja sebagai pengusaha kecil.

\section{Struktur Keagamaan dan Budaya Penduduk}

Struktur penduduk Desa Kedonganan menurut agama atau penganut kepercayaan yaitu mayoritas penduduk atau masyarakat menganut agama Hindu dengan persentase sebesar $90 \%$. PemelukAgama Hindu merupakan masyarakat asli Bali. Masyarakat pendatang menganut agama Islam, Kristen, Katholik, Budha. Desa Kedonganan masih lekat dengan budaya agama Hindu yang menganut ajaran Tri Hita Karana yaitu keseimbangan atau keharmonisan hidup antara manusia dengan Tuhan, manusia dengan manusia dan manusia dengan lingkungan. Secara administratif, penduduk yang tinggal di Desa Kedonganan mayoritas masyarakat etnis Bali dan sisanya masyarakat etnis Jawa dan China. Meskipun terdapat beberapa etnis dan budaya yang dibawa oleh masyarakat pendatang, namun masyarakat Desa Kedonganan hidup dengan rasa tenggang rasa dan toleransi.

\section{Potensi Sosial Budaya}

Masyarakat Desa Kedonganan masih terasa kental solidaritas sosialnya. Hal ini dapat terlihat dari adanya kelompok-kelompok masyarakat yang secara suka rela melakukan aktivitas gotong royong dalam membersihkan lingkungan, mengolah dan membuat fasilitas desa serta dalam mengatur pelaksanaan upacara kegamaan desa. Seperti hal nya para nelayan yang bergotong-royong dalam aktivitas membersihkan lingkungan pantai yang biasanya rutin dilakukan dua minggu sekali. Selain itu, budaya yang 
menjadi daya tarik adalah nelayan di pantai kedonganan yang masih banyak menggunakan jukung tradisional dalam menangkap ikan dan biasanya jukung tradisional tersebut disewakan kepada para wisatawan yang ingin menikmati keindahan pantai pada sore hari

Desa Kedonganan mempunyai beberapa pura untuk tempat beribadah dan tempat upacara keagamaan penduduk setempat yang memeluk agama Hindu. Pura-pura tersebut antara lain Pura Segara, Pura Penataran dan Pura tiga kahyangan yang terdiri dari Pura Puseh, Pura Desa dan Pura Dalem. Pura-pura tersebut mempunyai fungsi-fungsi yang diatur dalam Awig-awig yaitu Pura Puseh dan Pura Dalem untu melaksanakan upacara wuku dungulan, Pura Dalem untuk melaksanakan wuku kuningan, Pura Penataran untuk upacara wage kuningan dan Pura Segara untuk melaksanakan upacara purnama kedasa.

Masyarakat Desa Kedonganan berpegang teguh ada Awigawig dalam melaksanakan kehidupan sehari-hari. Awigawig dibuat berdasarkan landasan ajaran agama hindu yaitu Tri Hita Karana. Awig-awig merupakan aturan lokal atau aturan adat baik tertulis maupun tidak tertulis. Dalam bidang seni, masyarakat Desa Kedonganan mempunyai perkumpulan seni seperti Bali Musician Community (BMC), Sekaha Gong Sekha Budhi Sentana dan Sekaha Gong Wanita.

\section{Sistem Kemasyarakatan}

\section{Sistem Nilai dan Agama}

Penduduk Desa Kedonganan mayoritas memeluk Agama Hindu yaitu sebesar $90 \%$ dan merupakan penduduk asli Bali. Selain Agama Hindu ada juga penduduk yang memeluk agama lain seperti Agama Islam, Kristen, Katholik dan Budha yang merupakan penduduk pendatang. Baik penduduk pribumi maupun penduduk pendatang mempunyai rasa toleransi yang tinggi. Hal ini terlihat dar mulai terdapat beberapa tempat ibadah seperti mushola di Desa Kedonganan dan mereka saling menghargai ketika menjalankan ibadah. Sistem nilai yang dijalankan oleh masyarakat banyak berpegang teguh pada Awig-awigdesa yang mengatur keseimbangan hubungan atau keharmonisan hubungan antara manusia dengan manusia, manusia dengan Tuhan dan manusia dengan lingkungan. Ajaran Awig-awig berlandaskan ajaran Agama Hindu yaitu Tri Hita Karana karena penduduk pribumi menganut Agama Hindu dan Bali lekat dengan budaya Agama Hindu.

\section{Sistem dan Organisasi Sosial}

Desa Kedonganan terdiri dari desa dinas dan desa pakraman atau desa adat. Sistem masyarakat dan organisasi sosial masyarakat desa kedonganan dapat diamati melalui aspek kelembagaannya. Desa dinas dipimpin oleh seorang kepala desa yang bertugas untuk mengurus menjalankan pemerintahan desa sesuai dengan hukum formal yang berlaku serta mengurus masalah administrasi warga desa. Desa pakraman atau desa adat dipimpin oleh seorang bendesa adat yang bertugas mengatur kehidupan masyarakat berdasarkan adat-istiadat secara turun menurut sesuai dengan hukum adat yang berlaku seperti sistem norma, tradisi dan tata krama pergaulan hidup bermasyarakat. Adapun lembaga-lembaga yang terdapat di Desa Kedonganan dikelompokkan menjadi dua, yaitu :

\section{- Lembaga adat \\ - Lembaga formal atau dinas}

\section{Karakteristik Responden}

Karakteristik nelayan yang dijadikan responden dalam penelitian ini adalah 30 nelayan pribumi dan 30 nelayan pendatang. Nelayan yang menjadi responden dalam penelitian ini adalah nelayan yang rata-rata menggunakan alat perahu tradisional yang tidak memakai mesin atau nelayan yang memakai perahu 3 sampai 5 Gross Ton (GT). Pembagian karakteristik nelayan menjadi dua yaitu nelayan pribumi dan nelayan pendatang bertujuan untuk melihat perbandingan tingkat pengetahuan, pemahaman dan implementasi mereka terhadap aturan lokal yang dibuat berlandasakan ajaran agama hindu Tri Hita Karana. Nelayan pribumi sangat lekat dengan budaya dan ajaran agama Hindu dan nelayan pendatang yang datang dari budaya dan ajaran agama berbeda.

Nelayan yang menjadi responden merupakan nelayan pribumi dan nelayan pendatang yang melaut di Pantai Kedonganan. Lama bekerja sebagai nelayan merupakan lamanya waktu seseorang menjadi nelayan di Pantai Kedonganan walaupun tidak tinggal menetap di Desa Kedonganan. Dalam penelitian ini mengambil responden yang minimal bekerja sebagai nelayan selama enam bulan karena nelayan tersebut pernah melewati Hari Raya Nyepi, upacara keagamaan setempat dan musim yang dilarang untuk melaut.

Lama bekerja sebagai nelayan dibedakan menjadi tiga kategori yaitu lama bekerja selama 0-10 tahun, 11-20 tahun dan 21-30 tahun. Hasil penelitian terhadap responden menunjukkan bahwa lama bekerja nelayan pribumi paling banyak selama 11- 20 tahun yaitu berjumlah 15 orang atau mencapai 50\% sedangkan lama bekerja nelayan pendatang paling banyak selama $0-10$ tahun yaitu berjumlah 12 orang atau mencapai $40 \%$. Responden dalam penelitian ini mempunyai tingkat pendidikan yang beragam mulai dari Sekolah Dasar (SD), Sekolah Menengah Pertama (SMP) dan Sekolah Menengah Atas (SMA). Tingkat pendidikan nelayan adalah jenjang pendidikan terakhir yang ditempuh oleh nelayan. Hasil penelitian terhadap responden menunjukkan bahwa baik nelayan pribumi maupun nelayan pendatang banyak yang menempuh jenjang pendidikan sampai Sekolah Menengah Pertama (SMP) yaitu nelayan pribumi sebanyak 20 orang atau sebesar $66 \%$ dan nelayan pendatang sebanyak 17 orang atau sebesar $56 \%$

Kategori umur responden dalam penelitian ini menggunakan kategori umur menurut Havighurst yaitu usia 18-30 tahun yang dikategorikan sebagai usia dewasa awal, usia 31-55 tahun yang dikategorikan sebagai masa usia pertengahan dan 55 tahun keatas sebagai masa tua. Usia nelayan pribumi sebagian besar berada pada masa usia pertengahan yaitu sebanyak 22 orang atau sebesar $73 \%$ dan usia nelayan pendatang sebagian besar juga berada pada masa usia pertengahan yaitu sebanyak 19 orang atau sebesar $63 \%$. Nelayan pribumi yang menjadi responden dalam penelitian ini secara keseluruhan memeluk Agama Hindu yang menjadi agama mayoritas penduduk di Bali sedangkan nelayan pendatang sebesar $90 \%$ memeluk Agama Islam dan sisanya memeluk Agama Kristen.

Berdasarkan status penguasaan kapital, nelayan dibagi menjadi nelayan juragan dan nelayan buruh. Nelayan 
pemilik atau juragan adalah orang yang memilki sarana penangkapan seperti kapal, jaring dan alat tangkap lainnya. Sementara nelayan buruh adalah orang yang menjual jasa tenaga kerja sebagai buruh dalam kegiatan penangkapan ikan di laut atau sering disebut sebagai Anak Buah Kapal (ABK). Nelayan yang berada di Pantai Kedonganan pun terbagi atas nelayan juragan dan nelayan buruh.Jumlah nelayan pribumi yang merupakan nelayan buruh sebanyak 16 orang atau sebesar $53 \%$ dan jumlah nelayan pibumi yang merupakan nelayan juragan sebanyak 14 orang atau sebesar $47 \%$. Jumlah nelayan pendatang yang merupakan nelayan buruh sebanyak 17 orang atau sebesar $57 \%$ dan nelayan pendatang yang meupakan nelayan juragan sebanyak 13 orang atau sebesar $43 \%$.

Selain penggolongan berdasarkan status penguasaan kapital, nelayan juga digolongkan berdasarkan waktu yang digunakan untuk melakukan pekerjaan operasi penangkapan yaitu nelayan ikan penuh, nelayan ikan sambilan dan nelayan ikan sambilan tambahan. Nelayan ikan penuh adalah orang yang seluruh waktu kerjanya digunakan untuk melakukan pekerjaan operasi penangkapan ikan atau pemeliharaan ikan, nelayan ikan sambilan adalah orang yang sebagian besar waktu kerjanya digunakan untuk melakukan pekerjaan operasi penangkapan atau pemeliharaan ikan, sedangkan nelayan ikan sambilan tambahan adalah orang yang sebagian kecil waktu kerjanya digunakan untuk melakukan pekerjaan penangkapan atau pemeliharan ikan. Nelayan yang bekerja di Pantai Kedonganan termasuk golongan nelayan ikan penuh dan nelayan ikan sambilan. jumlah nelayan pribumi yang merupakan nelayan ikan penuh sebanyak 16 orang atau sebesar $53 \%$ dan jumlah nelayan pibumi yang merupakan nelayan ikan sambilan sebanyak 14 orang atau sebesar $47 \%$. Jumlah nelayan pendatang yang merupakan nelayan ikan penuh sebanyak 17 orang atau sebesar $57 \%$ dan nelayan pendatang yang meupakan nelayan ikan sambilan sebanyak 13 orang atau sebesar $43 \%$.

\section{BENTUK AWIG-AWIG YANG MENGATUR KEHIDUPAN MASYARAKAT NELAYAN}

Awig-awig merupakan sekumpulan aturan lokal setempat yang dibuat berdasarkan kesepakatan bersama untuk mengatur perilaku masyarakat setempat. Awig-awig merupakan bentuk dari kelembagaan lokal yang dibuat oleh bendesa adat beserta pengurus desa pakraman yang dapat berubah seiring perkembangan zaman dan sesuai kesepakatan bersama. Awig-awig tertulis Desa Kedonganan belum mengalami perubahan sejak tahun 1989 sehingga banyak yang berbentuk tidak tertulis. Desa Pakraman memberikan hak kepada kelompok nelayan untuk membuat Awig-awig yang berlaku bagi nelayan dalam pengaturan penangkapan ikan karena Desa Kedonganan terkenal sebagai desa nelayan. Awig-awig tersebut berlaku bagi semua nelayan yang menangkap ikan di Pantai Kedonganan. Seperti yang dituturkan oleh ketua kelompok nelayan (IKD/48 tahun):

“Awig-awig yang berlaku bagi nelayan dibuat berdasarkan kesepakatan bersama nelayan pribumi yang tergabung dalam kelompok nelayan. Ada beberapa Awig-awig yang memang berlaku untuk keseluruhan masyarakat dan tertuang dalam buku Awig-awig desa serta ada juga Awigawig yang tidak tertulis. Diharapkan Awig-awig dapat efektif mengatur perilaku nelayan agar lingkungan tetap terjaga kelestariannya, budaya yang dianut masyarakat tidak memudar dan untuk keselamatan para nelayan selama melaut"

Awig-awig dalam pengaturan penangkapan ikan yang berlaku bagi nelayan yang melaut di Desa Kedonganan terdiri dari tujuh aturan. Berikut rincian lebih jelas mengenai isi dari aturan lokal Awig-awig tersebut:

- Awig-awig nomor 1: Dilarang menangkap ikan menggunakan bom, potasium, racun, pukat harimau dan bahan kimia berbahaya lainnya. Aturan ini dibuat dengan tujuan agar tidak merusak biota laut dan tetap terjaga kelestariannya

- $\quad$ Awig-awig nomor 2: Dilarang merusak terumbu karang secara sengaja. Aturan tersebut meliputi larangan mengambil terumbu karang, membuang limbah secara sengaja ke wilayah yang banyak terumbu karang dan membuang jangkar di sekitar terumbu karang

- Awig-awig nomor 3: Dilarang mengambil biota laut yang dilindungi.

Biota laut yang dilindungi meliputi lumba-lumba, penyu belimbing, penyu hijau, penyu pipih, penyu ridel, penyu sisik, penyu tempayan, pelagic thresher (hiu monyet, tikusan, cucut pedang), bigeye thresher (hiu lancur, hiu lutung, hiu tikus, paitan) dan hiu common thresher. Untuk mempermudah nelayan mengetahui jenis-jenis biota laut yang dilindungi, dipasang sebuah papan besar di tepi pantai yang bertuliskan larangan menangkap, menyimpan diatas kapal, dipindahkan antar kapal, digudangkan, dijual dan ditawarkan untuk diperdagangkan baik berbentuk utuh maupun sebagian. Selain itu juga tertera gambar dan nama jenis-jenis biota laut yang dilindungi. Awig-awig tentang larangan mengambil biota laut yang dilindungi sudah ada sejak dahulu namun jenis biota lautnya tidak spesifik, sehingga Awig-awig tersebut diperbaharui dengan mengadopsi aturan pemerintah yang berlaku sekarang.

- Awig-awig nomor 4: Dilarang melaut pada saat Hari Raya Nyepi.

Aturan tersebut tidak hanya berlaku bagi nelayan melainkan berlaku bagi seluruh masyarakat Bali baik yang beragama Hindu maupun beragama lain. Pada Hari Raya Nyepi seluruh masyarakat Bali melakukan catur brata penyepian yaitu dilarang menyalakan api atau listrik (amati geni) kecuali jika di tempat tinggal nya ada bayi berumur kurang dari tiga bulan, ada orang yang sakit dan ada orang yang meninggal. Selain itu, terdapat larangan untuk bekerja (amati karya), larangan untuk tidak menikmati hiburan (amati lelanguan), dan larangan untuk tidak berpergian (amati lampah) kecuali bila dalam keadaan sakit dan perlu pergi ke rumah sakit ataupun alasan mendesak lainnya dengan didampingi tokoh desa adat setempat beserta pecalang. Bagi masyarakat yang melanggar akan dikenakan sanksi adat oleh pecalang. Aturan mengenai larangan melakukan aktivitas pada saat hari raya nyepi termasuk melaut, tertulis pada Awig-awig Desa Kedonganan pasal 68 (pawos 68) yang berisi :

1. Upacara rahina nyepi /sipeng patut kamargiang catur brata:

a. Amati geni, sajawaning

- Madruwe rare durung tiga sasih, ring genah rare inucap 
- Metepetin ring sang sungkan

- Madruwe layon, ring sawe inucap

b. Amati karya, tan kengin nyambut gawe sejawaning pecalang desa lan prajuru dines miwah sang polih uakuakan (ijin) antuk ilikita, pastika saking sang angawerat

c. Amati lampah, tan kengin melelungaan

d. Amati lelangunan, tan kengin masuara gora, maoneng-onengan (mepelalian) lsp

2. Prade wenten krama amurung brata penyepian, kaicen piceket-piceket/kedanda manut parerem

3. Riwus rahina nyepi kawastaning ngemak geni mapiteges pengelukaran yoga semadi kedulurin antuk pengaksama, soang-soang krama desa/banjar makacihna pangawit icaka warsa

- $\quad$ Awig-awig nomor 5: Dilarang melaut di sekitar Pantai Kedonganan pada saat dilaksanakan upacara desa setempat.

Aturan tersebut melarang nelayan untuk melaut di sekitar Pantai Kedonganan pada saat berlangsungnya upacara keagamaan desa setempat yang dilakukan di sekitar pantai atau di Pura Segara yang letaknya berada di pinggir Pantai Kedonganan. Upacara yang dilaksanakan di sekitar Pantai Kedonganan diantaranya adalah upacra purnama sasih kedasa, upacara melasti dan upacara ngaben. Upacara purnama kedasa adalah upacara yang dilaksanakan pada bulan purnama ke 10 di Pura Segara. Makna dari upacara ini adalah memohon berkah dan dan karunia dari Hyang Widi (Tuhan Yang Maha Esa) yang telah menerangi dunia berserta isinya. Pada upacara purnama kedasa, masyarakat melakukan sembahyang dan memohon kepada Tuhan agar diberi pengampunan dan disucikan lahir batin dari kesalahan-kesalahan baik sengaja maupun tidak sengaja. Upacara melasti adalah upacara yang dilakukan tiga hari sebelum Hari Raya Nyepi. Umat Hindu melakukan upacara dan sembahyang di tepi pantai dengan tujuan untuk mensucikan diri dari segala perbuatan buruk di masa lalu yang pernah dilakukan dan membuangnya ke laut. Upacara melasti dilaksanakan sebelum Tapa Brata Penyepian. Selain melakukan sembahyang, dilakukan juga penyucian benda-benda sakral milik Pura yang akan diarak keliling desa dengan tujuan untuk menyucikan desa dan selanjutnya dibawa ke laut untuk ritual penyucian terakhir. Upacara yang dilakukan di tepi pantai selanjutnya adalah upacara ngaben yaitu upacara pembakaran mayat yang dilakukan umat Hindu di Bali, upacara pembakaran jenazah ini dilakukan untuk menyucikan roh leluhur orang sudah wafat menuju ke tempat peristirahatan terakhir. Upacara ngaben dilaksanakan sebagai wujud kasih sayang dan penghormatan kepada orang yang telah meninggal. Jenazah orang yang meninggal tersebut akan diarak keliling desa sebelum menuju tempat pembakaran. Setelah jenasah dibakar, abu nya dimasukkan dalam buah kelapa gading kemudian dilakukan upacara pelarungan abu ke laut yang dianggap suci.

- $\quad$ Awig-awig nomor 6: Dilarang membuang sampah di sekitar pantai dan pesisir Kedonganan.

Aturan mengenai larangan membuang sampah di laut meliputi limbah, sampah organik maupun sampah non- organik. Aturan ini dibuat bertujuan agar kebersihan pantai dan kelestarian lingkungan pantai tetap terjaga karena pantai kedonganan termasuk pantai yang sering dikunjungi wisatawan domestik maupun mancanegara. Agar nelayan dan masyarakat tidak membuang sampah di sembarang tempat, maka disediakan tempat sampah yang letaknya di pinggir Pantai Kedonganan

\section{- $\quad$ Awig-awig nomor 7: Dilarang melaut pada saat} angin musim barat

Aturan mengenai larangan melaut pada angin musim barat ini bertujuan untuk menjaga keselamatan nelayan selama melaut. Angin musim barat biasanya berlangsung pada bulan Desember sampai Februari. Angin musim barat adalah angin yang mengalir dari Benua Asia menuju Benua Australia. Pada saat angin musim barat, angin bertiup sangat kencang, curah hujan tinggi dan gelombang laut menjadi tinggi. Nelayan di Pantai Kedonganan mengidentifikasikan musim angin barat ketika langit selalu terlihat gelap selama berhari-hari dan curah hujan tinggi antara bulan Desember sampai Februari. Bila tanda-tanda seperti yang disebutkan sudah terlihat, maka nelayan dilarang melaut demi keselamatan bersama. Larangan melaut pada musim angin barat juga biasanya diumumkan oleh polisi air setempat.

Awig-awig merupakan aturan lokal yang mengatur sistem perilaku atau tata kelakuan manusia dalam kehidupan masyarakat. Awig-awig berisi sekumpulan norma yang mempunyai beberapa tingkatan norma baik dalam bentuk tertulis maupun tidak tertulis. Sebagai wujud kontrol Awigawig agar dapat berjalan sesuai dengan nilai dan norma yang telah disepakati, maka diterapkan sanksi-sanksi bagi pihak yang melanggar aturan tersebut. Kontrol sosial bertujuan untuk mencapai keserasian antara stabilitas dengan perubahan-perubahan dalam masyarakat. Penerapan sanksi merupakan suatu wujud upaya represif. Sanksi tersebut ada yang bersifat ringan dan berat tergantung dengan jenis pelanggarannya. Seperti yang disampaikan oleh salah satu tokoh masyarakat (NS/50 tahun)

"Dalam setiap aturan dalam Awig-awig terdapat sanksi-sanksi yang sifatnya sebagai kontrol terhadap perilaku masyarakat. Sanksi-sanksi tersebut ada yang ringan dan ada yang berat tergantung jenis pelanggarannya. Setiap nelayan harus mematuhi dan mentaati Awig-awig tersebut. Dalam kebudayaan Bali, bagi yang melanggar Awig-awig akan dikenakan sanksi yang berlaku dan tidak memandang status sosial. Misalnya ada yang melanggar aturan mengenai larangan untuk berpergian pada saat Hari Raya Nyepi. Walaupun yang melanggar status sosial nya tinggi di masyarakat, namun tetap menerima hukuman dari pecalang berupa denda dan bersih-bersih lingkungan desa"

Sanksi yang berlaku berbeda-beda dalam setiap aturan. Berikut rincian sanksi dari setiap aturan yang berlaku:

- Sanksi pelanggaran Awig-awig nomor 1: Pembakaran jukung (perahu) dan tidak diperkenankan melaut di sekitar laut Kedonganan.

- Sanksi pelanggaran Awig-awig nomor 2: Penyitaan kapal selama beberapa hari dan pembayaran sejumlah denda.

- Sanksi pelanggaran Awig-awig nomor 3: Penyitaan 
kapal selama beberapa hari dan pembayaran sejumlah denda.

- Sanksi pelanggaran Awig-awig nomor 4: Membayar sejumlah denda dan mendapat hukuman bersih-bersih lingkungan desa.

- Sanksi pelanggaran Awig-awig nomor 5: Sanksi berupa teguran namun bila sudah sangat menganggu kekhidmatan beribadah maka akan mendapat hukuman membayar sejumlah denda atau hukuman bersihbersih lingkungan pantai.

- Sanksi pelanggaran Awig-awig nomor 6: Sanksi berupa teguran namun bila membuang sampah dengan jumlah yang sangat banyak maka akan dikenakan hukuman membayar denda.

- Sanksi pelanggaran Awig-awig nomor 7: Sanksi hanya berupa teguran karena aturan ini dibuat untuk melindungi keselamatan nelayan dari musibah akibat gelombang tinggi dan cuaca buruk.

Terdapat empat tingkatan norma berdasarkan sanksi dan pelanggarannya, mulai dari yang terlemah sampai dengan yang terkuat sanksinya yaitu cara (usage), kebiasaan (folkways), tata kelakuan (mores) dan adat (customes). Awig-awig nomor 2, 3 dan 4 termasuk dalam tingkatan norma tata kelakuan karena sanksi bagi yang melanggar berupa hukuman. Awig-awig nomor 5, 6 dan 7 termasuk dalam tingkatan norma kebiasaan karena hukuman bagi yang melanggar adalah berupa teguran dan secara moral akan merasa malu. Namun bila jenis pelanggarannya dianggap sangat berat, maka Awig-awig nomor 5 dan 6 dapat digolongkan dalam tingkatan norma tata kelakuan. Awig-awig nomor 1 termasuk dalam tingkatan norma adat karena sanksi bagi yang melanggar adalah tidak diperbolehkan lagi melaut di Pantai Kedonganan dengan kata lain nelayan mengeluarkan pelaku dari komunitasnya.

Sosialisasi aturan lokal perlu dilakukan sebagai bentuk proses penanaman atau transfer kebiasan atau nilai dan aturan dalam lingkungan masyarakat. Bentuk sosialisasi Awig-awig bagi nelayan dalam pengaturan kehidupan masyarakat nelayan dilakukan melalui beberapa cara diantaranya sosialisasi yang dilakukan secara lisan oleh tokoh masyarakat desa, tokoh pemerintah, ketua nelayan, penduduk pribumi serta sosialisasi melalui media tulisan. Sosialisasi yang dilakukan oleh pemerintah hanya diperoleh pihak-pihak tertentu saja sehingga tidak semua nelayan mendapatkan sosialisasi langsung dari pemerintah. Sosialisasi yang dilakukan oleh ketua kelompok nelayan biasanya dilakukan ketika diadakan pertemuan kelompok nelayan atau ketika mereka sedang berkumpul bersama khusunya kepada nelayan yang baru. Ketua kelompok nelayan juga dibantu oleh beberapa nelayan pribumi yang dituakan di Desa Kedonganan. Bentuk sosialisasi yang dilakukan oleh tokoh masyarakat desa biasanya gencar dilakukan ketika mendekati Hari Raya Nyepi atau ketika akan diadakan upacara kegamaan setempat. Bentuk sosialisasi melalui media tulisan yaitu terdapat papan yang berisi aturan larangan menangkap biota laut yang dilindungi dan juga terdapat Awig-awig tertulis yang dibukukan namun tidak ada buku khusus Awig-awig dalam mengatur kehidupan masyarakat nelayan, hanya peraturan mengenai larangan-larangan pada saat Hari Raya Nyepi yang terdapat di buku tersebut karena aturan tersebut berlaku bagi seluruh masyarakat desa. Selain terdapat tulisan yang berisi larangan dan peringatan, terdapat pula gambar-gambar dan nama jenis-jenis biota laut yang dilindungi untuk mempermudah nelayan mengetahui jenisjenis biota laut yang dilindungi.

\section{PENGETAHUAN, PEMAHAMAN DAN IMPLEMENTASI NELAYAN PRIBUMI DAN PENDATANG TERHADAP AWIG-AWIG}

Awig-awig dalam pengaturan kehidupan masyarakat nelayan memiliki tujuh aturan yaitu larangan menangkap ikan menggunakan pukat harimau, bom, potasium dan bahan kimia berbahaya lainnya, larangan merusak terumbu karang secara sengaja, larangan mengambil biota laut yang dilindungi, larangan melaut pada Hari Raya Nyepi, larangan melaut pada saat berlangsungnya upacara, larangan membuang sampah di sekitar pantai dan pesisir dan larangan melaut pada angin musim barat. Nelayan pribumi dan pendatang masing-masing mempunyai pengetahuan, pemahaman dan implementasi yang berbeda pada setiap aturan dalam Awig-awig tersebut. Dari data yang diperoleh menunjukkan bahwa pelanggaran terendah yang dilakukan oleh nelayan pribumi adalah pelanggaran terhadap Awig-awig nomor satu yaitu larangan mengambil ikan menggunakan pukat harimau, bom, potasium dan bahan kimia berbahaya lainnya serta Awig-awig nomor lima mengenai larangan melaut pada Hari Raya Nyepi.

Sebanyak 100\% respondennelayan pribumi yangmengetahui, memahami dan mengimplementasikan Awig-awig nomor satu dan sebanyak $100 \%$ responden nelayan pribumi yang mengetahui, memahami dan mengimplementasikan Awigawig nomor lima. Pelanggaran tertinggi yang dilakukan nelayan pribumi adalah pelanggaran terhadap Awigawig nomor enam yaitu larangan membuang sampah di sekitar pantai dan pesisir. Sebanyak $80 \%$ responden mengetahui Awig-awig nomor enam dan 20\% responden yang tidak mengetahui, $80 \%$ responden yang memahami dan $20 \%$ yang tidak memahami serta $40 \%$ responden yang mengimplementasikan dan $60 \%$ responden yang melanggar. Alasan nelayan pribumi yang melanggar Awigawig nomor 6 mengenai larangan membuang sampah di sekitar pantai dan pesisir:

1. Mereka hanya membuang sampah kecil seperti sampah bungkus rokok, putung rokok atau plastik kecil dan mereka menganggap sampah-sampah kecil tersebut tidak akan terlalu mengotori lingkungan secara besarbesaran

2. Mereka selalu rutin mengadakan kerja bakti di sekitar pantai setiap dua minggu sekali sehingga mereka merasa walaupun membuang sampah sembarangan namun mereka juga rutin mengadakan kerja bakti

3. Sanksi bagi yang membuang sampah dalam jumlah sedikit tidak terlalu memberatkan

4. Letak tempat sampah yang jarang sekali di tepi pantai dan di kapal mereka tidak ada tempat sampah sehingga mereka membuang sampah di laut.

Pelanggaran terendah yang dilakukan oleh nelayan pendatang adalah pelanggaran terhadap Awig-awig nomor satu. Sebanyak $100 \%$ responden nelayan pendatang yang mengetahui, memahami dan mengimplementasikan Awigawig nomor satu. Sedangkan pelanggaran tertinggi yang dilakukan oleh nelayan pendatang adalah pelanggaran terhadap Awig-awig nomor lima yaitu larangan melaut 
di sekitar pantai kedonganan pada saat berlangsungnya upacara keagamaan. Sebanyak $80 \%$ responden mengetahui Awig-awig nomor 6 dan 20\% responden yang tidak mengetahui, $80 \%$ responden yang memahami dan $20 \%$ yang tidak memahami serta $40 \%$ responden yang mengimplementasikan dan $60 \%$ responden yang melanggar. Alasan nelayan pendatang melanggar Awig-awig nomor 5:

1. Mereka mengaku bahwa mereka memahami dan mengerti mengenai larangan tersebut namun mereka merasa bahwa agama dan budaya lain jangan sampai terlalu mengikat mereka yang penting mereka saling menghargai.

2. Warga setempat juga sudah mempunyai rasa toleransi yang tinggi sehingga sanksi yang berlaku biasanya hanya berupa teguran bila menangkap ikan terlalu dekat dengan tempat berlangsung nya ibadah atau membayar sejumlah denda bila kegiatan menangkap ikan tersebut dianggap sudah mengganggu kekhidmatan upacara. Sanksi tersebut dianggap merupakan sanksi ringan bagi nelayan pendatang.

3. Nelayan pendatang menganggap bahwa jika mereka tidak melaut pada saat berlangsungnya upacara keagamaan setempat maka mereka tidak akan mendapat penghasilan sama sekali atau mendapatkan penghasilan yang sedikit.

Seiring berkembangnya zaman dan meningkatnya jumlah nelayan pendatang yang berasal dari berbaga daerah, Awigawig dalam pengaturan kehidupan masyarakat nelayan mengalami beberapa perubahan. Untuk menganalisa apakah Awig-awig masih dihargai dan menjadi pedoman hidup oleh nelayan, maka diukur tingkat pengetahuan, pemahaman dan implementasi nelayan terhadap keseluruhan Awig-awig dalam pengaturan penangkapan ikan. Dari hasil data yang diperoleh, $100 \%$ nelayan pribumi dan pendatang memiliki tingkat pengetahuan yang tinggi terhadap Awig-awig, 97\% nelayan pribumi yang memiliki tingkat pemahaman tinggi dan $100 \%$ nelayan pendatang yang memiliki tingkat pemahaman yang tinggi serta $90 \%$ nelayan pribumi yang memiliki implementasi tinggi dan $83 \%$ nelayan pendatang yang memiliki implementasi tinggi.

Nelayan pribumi dan nelayan pendatang memiliki tingkat pengetahuan, pemahaman dan implementasi yang tinggi terhadap keseluruhan aturan dalam Awig-awig walaupun dengan persentase yang berbeda. Hal ini menunjukkan bahwa Awig-awig masih menjadi pedoman hidup nelayan kedonganan dan masih dihargai keberadaannya meskipun perlu ada beberapa perbaikan untuk meningkatkan keefektivitasan Awig-awig. Jumlah responden yang mengetahui dan memahami keseluruhan Awig-awig dalam pengaturan kehidupan masyarakat nelayan mulai dari Awig-awig nomor 1 sampai nomor 7 lebih banyak berasal dari nelayan pendatang daripada nelayan pribumi. Hal ini karena nelayan pendatang jika datang ke sebuah tempat yang bukan daerah asal mereka untuk mencari nafkah, maka mereka cenderung untuk ingin mengetahui dan mempelajari aturan yang berlaku di daerah tersebut agar mereka bisa beradaptasi. Akan tetapi jumlah responden yang mengimplementasikan keseluruhan Awig-awig dalam pengaturan kehidupan masyarakat nelayan lebih banyak berasal dari nelayan pribumi daripada nelayan pendatang. Hal ini karena mereka taat pada budaya dan ajaran Agama Hindu yang terkandung dalam Awig-awig yaitu Tri Hita

\section{Karana.}

\section{EFEKTIVITAS AWIG-AWIG DALAM PENGATURAN KEHIDUPAN MASYARAKAT NELAYAN}

Efektivitas Awig-awig dalam pengaturan kehidupan masyarakat nelayan dapat dinilai dari kemampuan Awigawig tersebut dalam mengatur perilaku nelayan yang dapat dilihat dari tingkat pelanggaran yang terjadi. Tingkat pelanggaran terbagi menjadi dua yaitu tingkat pelanggaran sedang dan tingkat pelanggaran tinggi. Tingkat pelanggaran sedang dibagi menjadi dua kategori yaitu kategori aman jika jumlah pelanggaran sebesar $0 \%-24 \%$ dan kategori pelanggaran kurang serius jika jumlah pelanggaran sebesar $25 \%-49 \%$. Tingkat pelanggaran tinggi dibagi menjadi dua kategori yaitu pelanggaran serius jika jumlah pelanggaran sebesar 50\%-74\% dan pelanggaran sangat serius jika jumlah pelanggaran sebesar 75\%-100\%. Awig-awig dikatakan efektif mengatur perilaku nelayan jika berada pada tingkat pelanggaran sedang dan Awig-awig dikatakan kurang efektif mengatur perilaku nelayan jika berada pada tingkat pelanggaran tinggi.

Selain dilihat dari tingkat efektivitas dalam mengatur perilaku nelayan, keefektivitasan Awig-awig dapat dilihat dari beberapa hal seperti bentuk sosialisasi, bentuk sanksi-sanksi yang diterapkan, petugas yang memantau, kesadaran nelayan, kondisi nelayan, ketersediaan sarana dan prasarana serta kondisi wilayah. Keefektivitasan Awigawig ini dianalisis dengan tujuan untuk mengetahui apakah Awig-awig efektif dalam mengatur perilaku nelayan dan efektif diterapkan di Pantai Kedonganan. Dalam bab ini akan dibahas mengenai efektivitas masing-masing aturan dalam Awig-awig yang dilihat dari tingkat efektivitas dalam mengatur perilaku nelayan dan dari berbagai aspek baik nelayan pribumi maupun nelayan pendatang.

Efektivitas Awig-awig dianalisis untuk mengetahui sejauh mana Awig-awig tersebut efektif diterapkan di Pantai Kedonganan. Keefektivitasan Awig-awig dapat dilihat dari kemampuan Awig-awig tersebut dalam mengatur perilaku nelayan. Dari data yang diperoleh menunjukkan bahwa Awig-awig yang paling efektif mengatur perilaku nelayan pribumi adalah Awig-awig nomor satu mengenai larangan menangkap ikan menggunakan pukat harimau, bom, potasium dan bahan kimia berbahaya lainnya serta. Awigawig nomor satu dikatakan sangat efektif karena:

1. Jumlah pelanggaran responden sebesar $0 \%$. Alasan mereka mentaati Awig-awig nomor satu adalah karena mereka menganggap perbuatan menangkap menggunakan pukat harimau, bom, potasium dan bahan kimia berbahaya lainnya merupakan perbuatan yang menyebabkan biota laut musnah dan laut akan tercemar sehingga mata pencaharian mereka akan berkurang. Laut merupakan anugerah dari Sang Hyang Widi yang harus mereka jaga apalagi mereka adalah penduduk asli daerah Pantai Kedonganan.

2. Sanksi adat maupun sanksi dari pemerintah yang sangat berat dan petugas yang selalu melakukan patroli menyebabkan mereka tidak melanggar aturan tersebut.

Selain Awig-awig nomor satu, Awig-awig yang juga sangat efektif mengatur perilaku nelayan pribumi adalah Awig-awig nomor empat mengenai larangan melaut pada Hari Raya Nyepi. Alasan nelayan pribumi mentaati Awig-awig nomor empat adalah karena seluruh nelayan 
pribumi memeluk Agama Hindu dan Hari Raya Nyepi merupakan hari yang suci bagi mereka sehingga pada hari tersebut mereka benar-benar khusuk melakukan ibadah. Awig-awig yang kurang efektif dalam mengatur perilaku nelayan pribumi adalah Awig-awig nomor empat mengenai larangan membuang sampah di sekitar pantai dan pesisir. Alasan mereka melanggar aturan tersebut adalah karena mereka hanya membuang sampah kecil dan tidak dalam jumlah besar serta keberadaan tempat sampah yang jarang.

Awig-awig yang paling efektif mengatur perilaku nelayan pendatang adalah Awig-awig nomor satu. Alasan mereka mentaati aturan tersebut sama seperti alasan nelayan pribumi, yaitu:

1. Mereka menganggap perbuatan tersebut kejam karena akan sangat merusak lingkungan.

2. Sanksi yang tegas baik sanksi adat maupun sanksi formal dan petugas yang selalu melakukan kontrol.

3. Larangan menggunakan pukat harimau, bom, potasium dan bahan berbahaya lainnya juga merupakan aturan pemerintah sehingga sosialisasi nya pun gencar di lakukan di seluruh perairan Indonesia dan bukan hanya di Pantai Kedonganan saja.

Awig-awig yang kurang efektif mengatur perilaku nelayan pendatang adalah Awig-awig nomor lima mengenai larangan melaut di sekitar pantai pada saat berlangsungnya upacara keagamaan. Alasan mereka melanggar aturan tersebut adalah mereka merasa bahwa agama dan budaya lain jangan sampai terlalu mengikat mereka yang penting mereka saling menghargai. Jika mereka tidak melaut pada saat upacara keagamaan berlangsung, maka mereka akan mendapatkan hasil tangkapan yang sedikit.

Awig-awig yang paling efektif diterapkan adalah Awigawig nomor satu dan Awig-awig nomor empat. Hal ini dilihat dari jumlah pelanggaran yang rendah, sanksi yang tegas, kesadaran nelayan yang tinggi, petugas yang selalu melakukan kontrol serta bentuk sosialisasi yang gencar dilakukan pemerintah maupun tokoh masyarakat. Awigawig yang kurang efektif diterapkan adalah Awig-awig nomor enam mengenai larangan membuang sampah di sekitar pantai dan pesisir. Awig-awig tersebut dikatakan kurang efektif disebabkan oleh beberapa hal, antara lain:

1. Jumlah pelanggaran yang tinggi

2. Sarana yang kurang memadai seperti tidak adanya tempat sampah di setiap kapal dan tempat sampah yang kurang menyebar di sekitar pantai

3. Petugas yang tidak bisa selalu melakukan kontrol

4. Sanksi yang kurang tegas dan kesadaran nelayan yang kurang akan kebersihan pantai seperti menganggap bahwa sampah kecil tidak masalah bila dibuang di pantai padahal sampah kecil akan menjadi sampah yang menumpuk bila dilakukan terus-menerus. Selain itu, untuk menjaga kebersihan lingkungan pantai juga perlu adanya partisipasi dari pedagang, masyarakat sekitar dan pengunjung.

Hasil penelitian menunjukkan bahwa, Awig-awig nomor 1 berada pada tingkat pelanggaran sedang yaitu dalam kategori aman bagi nelayan pribumi maupun nelayan pendatang. Awig-awig nomor 2 berada pada tingkat pelanggaran sedang yaitu dalam kategori pelanggaran kurang serius bagi nelayan pribumi maupun nelayan pendatang. Awig-awig nomor 3 jika dilihat dari jumlah pelanggaran yang dilakukan oleh nelayan pribumi maupun nelayan pendatang, berada pada tingkat pelanggaran sedang yaitu dalam kategori aman. Awig-awig nomor 4 berada pada tingkat pelanggaran sedang yaitu dalam kategori aman bagi nelayan pribumi maupun pendatang, sedangkan Awig-awig nomor 5 berada pada tingkat pelanggaran sedang yaitu dalam kategori aman bagi nelayan pribumi dan berada pada tingkat pelanggaran tinggi yaitu dalam kategori pelanggaran serius bagi nelayan pendatang. Awigawig nomor 6 berada pada tingkat pelanggaran tinggi yaitu dalam kategori pelanggaran serius bagi nelayan pribumi dan nelayan pendatang, sedangkan Awig-awig nomor 7 berada pada tingkat pelanggaran sedang yaitu dalam kategori pelanggaran kurang serius bagi nelayan pribumi maupun nelayan pendatang.

\section{KESIMPULAN DAN SARAN}

\section{Kesimpulan}

Bentuk-bentuk Awig-awig dalam pengaturan kehidupan masyarakat nelayan bagi terdiriatas tujuh aturan, diantaranya:

1. Larangan menangkap ikan menggunakan pukat harimau, bom, potasium dan bahan kimia berbahaya lainnya.

2. Larangan merusak terumbu karang secara sengaja.

3. Larangan mengambil biota laut yang dilindungi.

4. Larangan melaut pada Hari Raya Nyepi.

5. Larangan melaut di sekitar pantai dan pesisir kedonganan pada saat berlangsungnya upacara keagamaan.

6. Larangan membuang sampah di sekitar pantai dan pesisir.

7. Larangan melaut pada angin musim barat

Terdapat perbedaan pengetahuan, pemahaman dan implementasi antara nelayan pribumi dan nelayan pendatang. Hal ini dapat dilihat dari jumlah responden yang mengetahui, memahami dan mengimplementasi keseluruhan Awig-awig yang mengatur kehidupan masyarakat nelayan di Pantai Kedonganan. Jumlah responden yang mengetahui dan memahami keseluruhan Awig-awig dalam pengaturan kehidupan masyarakat nelayan mulai dari Awig-awig nomor 1 sampai nomor 7 lebih banyak berasal dari nelayan pendatang daripada nelayan pribumi. Hal ini karena nelayan pendatang jika datang ke sebuah tempat yang bukan daerah asal mereka untuk mencari nafkah, maka mereka cenderung untuk ingin mengetahui dan mempelajari aturan yang berlaku di daerah tersebut agar mereka bisa beradaptasi. Akan tetapi jumlah responden yang mengimplementasikan keseluruhan Awigawig dalam pengaturan kehidupan masyarakat nelayan lebih banyak berasal dari nelayan pribumi daripada nelayan pendatang. Hal ini karena mereka taat pada budaya dan ajaran Agama Hindu yang terkandung dalam Awig-awig yaitu Tri Hita Karana. Awig-awig yang paling efektif dalam mengatur perilaku nelayan adalah Awig-awig nomor 1 mengenai larangan menangkap ikan menggunakan bom, potasium, racun, pukat harimau dan bahan kimia berbahaya lainnya. Hal ini terlihat dari jumlah responden sebanyak $100 \%$ yang mentaati aturan tersebut. Selain itu juga dapat 
terlihat dari sosialisasi yang gencar dilakukan, petugas yang selalu mengadakan patroli, kesadaran nelayan akan bahaya dari penggunaan alat-alat tersebut dan sanksi yang tegas. Awig-awig dalam pengaturan kehidupan masyarakat nelayan secara keseluruhan paling efektif mengatur nelayan pribumi daripada nelayan pendatang karena jumlah responden yang mengimplementasikan keseluruhan aturan lebih banyak berasal dari nelayan pribumi. Maka hipotesis 1 dan hipoetesis 2 dapat diterima.

\section{Saran}

Untuk meningkat keefektivitasan Awig-awig maka perlu dilakukan evaluasi terhadap beberapa peraturan sehingga dapat dilakukan perbaikan. Evaluasi tersebut dapat meliputi bentuk sosialisasi, bentuk sanksi-sanksi yang diterapkan, petugas yang memantau, kesadaran nelayan, kondisi nelayan, ketersediaan sarana dan prasarana serta kondisi wilayah. Untuk selanjutnya diharapkan aturan-aturan dalam Awig-awig tersebut dibuat dalam bentuk tulisan dan diletakkan di tempat yang dapat dijangkau oleh para nelayan sehingga nelayan dapat terus mengingat aturan tersebut. Sanksi-sanksi yang diterapkan pun harus lebih tegas dan jumlah petugas yang memantau ditingkatkan.

\section{DAFTAR PUSTAKA}

Afiati N. 1999. Aspek Hayati Teknik Pengendalian Pencemaran dan Kerusakan Lingkungan Pesisir Semarang (ID): Bapedalda.

Astiti TIP, Windia W, Sudantra IK, Wijaatmaja IGM, Dewi AAIAA. 2011. Implementasi Ajaran Tri Hita Karana. [jurnal]. Denpasar (ID): Universitas Udayana.

[Bappenas] Badan Perencanaan Pembangunan Nasional. 2004. Kebijakan Pembangunan Pesisir Sebagai Alternatif. [Internet]. [diunduh1Maret 2013]. Tersedia pada: http://www.bappenas.go.id/get-fileserver/node/3007/

Bengen DG. 2001. Ekosistem dan Sumber Daya Alam Pesisir dan Lautan Secara Terpadu. Jakarta (ID): PT Pramadya Pramita.

Dahuri R, Rais J, Ginting SP, Sitepu MJ. 2004. Pengelolaan Sumber Daya Pesisir dan Lautan Secara Terpadu. Jakarta (ID): PT Pramadya Pramita.

Djogo T, Sunaryo, Suharjito D, Sirait M. 2003. Kelembagaan Kebijakan Dalam Agroforesti. Bogor (ID): ICRAF.

Hutagalung RA.2010. Ekologi Dasar. [internet]. [diunduh 1 Maret 2013]. Tersedia pada: http://id.wikipedia. org/wiki/Tragedi_Kepemilikan_Bersama\#cite ref-b_2-0

Koentjaraningrat. 1990. Pengantar Antropologi. Jakarta (ID): Penerbit Universitas.

Mugniesyah SS. 2006. Materi Bahan Ajar Ilmu Penyuluhan. Bogor: Institut Pertanian Bogor.

Nasution Z, Sastrawidjaja, Hartono TT, Mursidan, Priyatna FN. 2007. Sosial Budaya Masyarakat Nelayan. Jakarta (ID): Badan Riset Kelautan dan Perikanan.
[PM] Peraturan Menteri Perumahan Rakyat No. 15 tahun 2006 pasal 1:(14).

Saba ES. 2003. Penguatan Makna dan Peran Awig-awig Dalam

Pengelolaan Sumberdaya Perikanan. [tesis]. Bogor [ID]: Institut Pertanian Bogor.

Sartini. 2004. Menggali Kearifan Lokal Nusantara Sebuah Kajian Filsafati. [jurnal]. [internet]. [diunduh 1 Maret 2013]. Tersedia pada: http:// dgi-indonesia.com/wp-content/uploads/2009/02/ menggalikearifanlokalnusantara1.pdf

Satria A. 2002. Pengantar Sosiologi Masyarakat Pesisir. Jakarta (ID): Cidesindo.

Setiadi EM, Kolip U. 2011. Pengantar Sosiologi: Pemahaman Fakta dan Gejala Permasalahan Sosial. Jakarta (ID): Kencana Prenada Media Grup.

Singarimbun M dan Masri S. 2008. Metode Penelitian Survai. Jakarta (ID): Penerbit Pustaka LP3ES.

Sirait E. 2005. Pengelolaan Sumberdaya Berbasis Kemasyarakatan dan Kearifan Lokal : Studi Kasus Pengelolaan Cendana di Kabupaten Timor Tengah Selatan Provinsi Nusa TenggaraTimur. [Disertasi]. Bogor (ID): Institut Pertanian Bogor.

Soekanto S. 1990. Sosiologi Suatu Pengantar. Jakarta (ID): PT Raja Grafindo Persada.

Stanis S. 2005. Pengelolaan sumberdaya pesisir dan laut melalui pemberdayaan kearifan lokal di Kabupaten Lembata Propinsi Nusa Tenggara Timur.[tesis] . Semarang (ID): Universitas Diponegoro. 116 hal.

Sub Direktorat Data dan Perikanan Tangkap. 2011. Statistik Perikanan Tangkap Indonesia, 2010. Jakarta (ID): Direktorat Jenderal Perikanan Tangkap

Sumardjono MS. 2008. Tanah dalam Perspektif Hak Ekonomi, Sosial, Budaya. Jakarta (ID): Penerbit Buku Kompas.

Sunaryo. 2002. Psikologi Untuk Keperawatan. Jakarta (ID): EGC

Suasthawa DIM. 2001. Desa Adat Kesatuan Masyarakat Hukum Adat di Propinsi Bali. Denpasar (ID): Upada Sastra.

Tony F. 2003. Kelembagaan Sosial. Di dalam: Kolopaking LM, Sitorus MTF, Sumarti T, Dharmawan AH, Nawireja IK., editor. Sosiologi Umum. Bogor (ID): Institut Pertanian Bogor. hlm 29-35.

Wasistiono S dan Tahir M. 2007. Prospek Pengembangan Desa. Jakarta (ID): Fokus Media. 